UDC 657:338.2:339

JEL Classification: M2; M4

DOI: https://doi.org/10.35774/visnyk2020.04.127

\author{
Vasyl ZDRENYK, \\ $\mathrm{PhD}$ (Economics), Associate Professor of Management, Public Administration and \\ Personnel department, \\ West Ukrainian National University, \\ 11 Lvivska street, Ternopil city, 46000, Ukraine, \\ e-mail: zvs2011@ukr.net \\ ORCID ID: https://orcid.org/0000-0003-3373-8485
}

\title{
FORMATION OF AN EFFECTIVE POLICY FOR THE REPAYMENT OF ACCOUNTS RECEIVABLE AT THE ENTERPRISE
}

Zdrenyk, V. (2020). Formuvannya efektyvnoyi polityky pogashennya debitorskoyi zaborgovanosti na pidpryyemstvi [Formation of an effective policy for the repayment of accounts receivable at the enterprise]. The Herald of Ternopil National Economic University. 2020. Vol. 4. P.127-137. DOI: https://doi.org/10.35774/visnyk2020.04.127

ЗдреникВ. Формування ефективноїполітикипогашеннядебіторської заборгованості на підприємстві. Вісник Тернопільського національного економічного університету. 2020. Вип. 4. С.127-137. DOI: https://doi.org/10.35774/visnyk2020.04.127

\section{Abstract}

Introduction. Trade enterprises in modern conditions have significantly increased the volume of their activities. However, the uncertainty of the external environment and the presence of a number of different problems in the economy as a whole create obstacles to the timely fulfillment of obligations. This necessitates the formation of an effective policy for the repayment of accounts receivable at the enterprise.

Objective. The objective of the article is to substantiate the theoretical foundations and develop practical recommendations for the formation of an effective policy for the repayment of receivables at trade enterprises.

Methods. To establish the stages of the formation of the policy of repayment of receivables and its constituent elements, analytical empiricism was used with an orientation to the existing initial conditions and foreign experience. The study used the method of assessment and generalization to develop and substantiate proposals aimed at solving the problem of recognizing receivables as uncollectible, as well as to substantiate the approach to the classification of reserves and the calculation of reserves for doubtful debts.

Results. A conceptual approach to the formation of an effective policy for the repayment of accounts receivable from trade enterprises has been formed. The study substantiates that the effective development of a trading enterprise is possible due to the combination of such important components of its activities as a good information base of management and an (C) Vasyl Zdrenyk, 2020. 
effective policy for repayment of receivables. The result of the study is also the substantiation of the stages of formation of the policy of repayment of receivables, the development of proposals for its assessment and the formation of reserves for doubtful debts.

Discussion. A promising area of further research is the development of methods of analysis of receivables by actual indicators, the study of opportunities to improve communication and the formation of information support for trade and technological processes based on the use of modern information systems.

Keywords: trading company; receivables repayment policy; accounting policy; improvement; efficiency.

Formulas: 0, fig.: 1, tabl.: 4, bibl.: 16.

\section{ВасиЛЬ ЗДРЕНИК,}

\section{кандидат економічних наук, доцент,}

доцент кафедри менеджменту, публічного управління та персоналу,

Західноукраїнський національний університет,

вул. Львівська, 11, м. Тернопіль, 46009, Україна, e-mail: zvs2011@ukr.net

ORCID ID: https://orcid.org/0000-0003-3373-8485

\section{ФОРМУВАННЯ ЕФЕКТИВНОЇ ПОЛІТИКИ ПОГАШЕННЯ ДЕБІТОРСЬКОЇ ЗАБОРГОВАНОСТІ НА ПІДПРИЄМСТВІ}

\section{Анотація}

Вступ. Підприємства торгівлі в сучасних умовах суттєво наростили обсяги своєї діяльності. Проте невизначеність зовнішнього середовища та наявність різноманітних проблем в економіці загалом створюють перепони для своєчасного виконання зобов'язань. Це викликає необхідність фрормування ефрективної політики погашення дебіторської заборгованості на підприємстві.

Мета. Мета дослідження полягає в обгрунтувані теоретичних засад і наданні практичних рекомендацій щодо формування ефективної політики погашення дебіторської заборгованості на підприємствах торгівлі.

Методи дослідження. Для встановлення й ідентифікації етапів формування політики погашення дебіторської заборгованості та їі складових елементів використано аналітичну емпірику з орієнтацією на наявні вихідні умови та зарубіжний досвід. У досліджені використано метод оцінювання та узагальнення для: розробки й обгрунтування пропозицій, спрямованих на вирішення проблеми визнання дебіторської заборгованості безнадійною та обгрунтування підходу до класифрікації резервів і розрахунку резервів сумнівних боргів.

Результати. Сформовано концептуальний підхід до впровадження ефективної політики погашення дебіторської заборгованості торговельних підприємств. У досліджені обгрунтовано, що ефективний розвиток торговельного підприємства можливий завдяки поєднанню таких важливих компонентів його діяльності, як якісна інфрормаційна база управління та дієва політика щодо погашення дебіторської заборгованості. Результатом дослідження є також обґрунтування етапів формування політики погашення дебіторської заборгованості, розробка пропозицій щодо їі оцінювання та формування резервів сумнівних боргів. 
Перспективи. Перспективним напрямом подальших досліджень є розвиток методики аналізу дебіторської заборгованості за фрактичними показниками, дослідження можливостей поліпшення комунікативних зв'язків і фрормування інфрормаційної підтримки торгово-технологічних процесів на базі використання сучасних інформаційних систем.

Ключові слова: торговельне підприємство; політика погашення дебіторської заборгованості; облікова політика; удосконалення; ефективність.

Формули: 0, рис.: 1, табл.: 4, бібл.: 16.

Problem formulation. Settlements are an important element of cooperation between business entities. They form an integral part of commodity-money relations in a market environment. Accounts receivable and payable are important indicators characterizing the state of settlements of trade enterprises. In conditions of instability, there is a problem of a shortage of working capital, low payment discipline and untimely payments for obligations. These factors lead to a crisis of non-payments. Therefore, it is very important to use all possible levers to overcome this problem to the maximum. An effective lever for its solution is, in our opinion, the system of accounting for liabilities. Thanks to this particular system, certain mechanisms of influence can be involved, contributing to the acceleration of settlements or mechanisms that mitigate the risks of non-payment by counterparties. Therefore, the study of opportunities to improve the financial condition of enterprises through the use of an effective policy for repayment of receivables is an urgent area of research. Accounting is a complex system consisting of a number of interrelated elements. Their purpose is to ensure the efficient functioning of the enterprise. This system is able to qualitatively play the role of a mechanism for ensuring the rational use of time and resources at the enterprise. At the same time, it itself is an object of improvement through the scientific substantiation of its rational organization. For commercial enterprises in modern conditions, the task of developing and improving accounting is very important. Therefore, it is very important to improve its organization. This problem is especially relevant in matters of accounting policies relating to receivables. This situation complicates not only the organization of settlements, but also negatively affects the results of the activities of trade enterprises. In turn, among other important factors, ultimately the receivables settlement policy affects the growth rate of trade in goods and services. Table 1 shows such indicators in dynamics for 2014-2020.

Table 1

Growth rate of trade in goods and services, \% (to the previous period) (on the example of Ukraine)

\begin{tabular}{|c|c|c|c|}
\hline & Exports & Imports & Balance, mln. USD \\
\hline 2014 & 85,7 & 72,9 & 3356,2 \\
\hline 2015 & 73,0 & 70,7 & 3828,2 \\
\hline 2016 & 96,4 & 103,7 & 541,6 \\
\hline 2017 & 116,6 & 123,6 & $-2501,1$ \\
\hline 2018 & 108,9 & 115,3 & $-6212,8$ \\
\hline 2019 & 111,8 & 106,7 & $-3689,1$ \\
\hline 2020 January-March & 99,2 & 96,3 & $-9,4$ \\
\hline
\end{tabular}

Notes: data source [1, p.14] 
In percentage terms, the data provided in Table 1 are shown in Table 2.

Table 2

Increase, decrease (-) of trade in goods and services, \% (to the previous period) (on the example of Ukraine)

\begin{tabular}{|c|c|c|c|c|c|c|c|}
\hline & 2014 & 2015 & 2016 & 2017 & 2018 & 2019 & $\begin{array}{c}2020 \\
\text { January-March }\end{array}$ \\
\hline Exports & $-14,3$ & $-27,0$ & $-3,6$ & $+16,6$ & $+8,9$ & $+11,8$ & $-0,8$ \\
\hline Imports & $-27,1$ & $-29,3$ & $+3,7$ & $+23,6$ & $+15,3$ & $+6,7$ & $-3,7$ \\
\hline
\end{tabular}

Notes: data source [1, p.14]

The above statistics are an example of the importance of researching mechanisms to improve payment discipline and improve policies for repaying receivables for many reasons. In particular, due to the growth in recent years in the volume of trade operations in import and export. And besides this, in connection with the crisis impact on the state of trade of the Ukrainian economy. In modern conditions, the Ukrainian economy, like the economies of other countries, is highly influenced by the coronavirus pandemic.

Analysis of recent research and publications. Against the background of increasing sales, the existence of the fact of imperfection of the current policy of repayment of obligations is an important reason for the implementation of scientific research. The works of many scientists are devoted to the problems of improving the policy of repayment of accounts receivable, calculating insurance reserves and their reflection in accounting.

Issues related to the repayment of receivables, its accounting and control are actively discussed in economics Science. Scientists and practitioners widely cover the accounting procedure, the formation of accounting policies for receivables, the problem of reducing the risks associated with the implementation of commodity transactions and the crisis of default.

In particular, these important issues were studied by Akimova N. [2], Makogin Z. [3], Zhytny P. [4], Onyshchenko V. [5], Sviridenko A. [6], Fadeev Yu. [7], Yancheva L. [8] and many others. Thanks to the research of these, as well as many other scientists, many issues related to the repayment of receivables have been resolved.

Setting objectives. The purpose of the study is to substantiate the stages of formation of the accounting policy of the enterprise on the repayment of receivables, development of proposals for the formation of insurance reserves and classification of receivables.

Presentation of the main material of the study. The established norms and requirements, according to which the Order on accounting policy is formed, make it an important legal document on the issues of regulation of accounting at the enterprise.

It is necessary to follow a certain procedural sequence in the formation of accounting policies. It should be noted that this issue has not yet been resolved at the legislative level.

Therefore, there are different views on the stages of formation of accounting policies. In particular, scientists determine the different number of stages of accounting policy development and their different content (Table 3). 
Stages of formation of the accounting policy of the enterprise *

\begin{tabular}{|c|l|}
\hline Author & \multicolumn{1}{|c|}{ Name and content of the stage } \\
\hline $\begin{array}{c}\text { Zhytnyy P. } \\
\text { [4, p.7] }\end{array}$ & $\begin{array}{l}\text { Organizational; preparatory; identification of external conditions, phenomena and } \\
\text { processes that affect the development of accounting policies; formation of internal } \\
\text { environment factors; selection of elements of accounting policy for the objects } \\
\text { identified in the previous stages; information support of the accounting policy } \\
\text { formation process; final stage (registration and approval of the basic administrative } \\
\text { document). }\end{array}$ \\
\hline Kolos I. [9, p.47] & Organizational; preparatory; technological; the result \\
\hline Modern & $\begin{array}{l}\text { Determining the objects of accounting for which an accounting policy should be } \\
\text { developed; identification, analysis, assessment of factors under the influence of } \\
\text { economic } \\
\text { which the choice of methods of accounting; selection and justification of the initial } \\
\text { provisions for the construction of accounting policies; identification of potentially } \\
\text { suitable for use by the enterprise methods of accounting for each method and for } \\
\text { each object of accounting; registration of the chosen accounting policy. }\end{array}$ \\
\hline
\end{tabular}

Notes: * - formed on the basis of a sample of scientific works

In general, the process of formation of accounting policy should be carried out in such a sequence that would take into account the needs of management entities, i.e. it should be formed in at least 9 stages (Fig. 1).

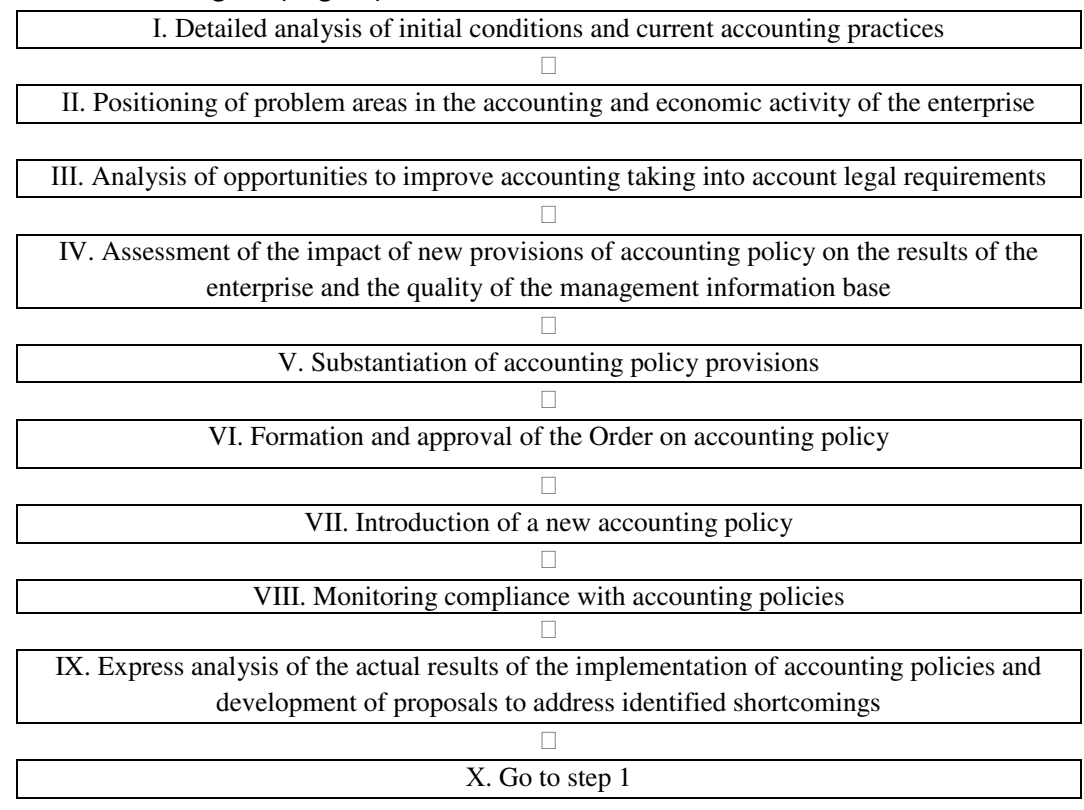

Fig. 1. Recommended stages of accounting policy formation *

Notes: * - formed on the basis of generalization and analysis of existing recommendations and needs of practice

The developed sequence of formation of accounting policy simplifies its drawing up, and also provides logical completion of this process.

For commercial enterprises in the formation of accounting policies it is important to assess receivables. 
Gryaznova A. and Fedotova M. claim that there are about ten methods for assessing receivables. The authors classify these methods into three groups:

- legal assessment (on the principle of nominalism);

- economic evaluation (on the principle of time value);

- accounting valuation (on the principle of nominalism) [11, p.205-206].

The economic estimate is based on the calculation of the impairment of liabilities for the period from the date of their occurrence to the maturity date. Impairment is usually related to inflation and interest rates. The economic concept of valuing liabilities is based on the laws of supply and demand, as well as the principle of competition. In accounting, it is the present value of future income and expenses.

Accounting valuation is carried out in accordance with the recommendations of the Regulations (standards) of accounting, which belong to the regulations, and therefore comply with the legal principle.

The general rules for estimating liabilities, including settlements for commodity transactions in Ukraine, are regulated by the UAS. Instead, in accordance with the requirements of IFRS, debts should be assessed depending on the probability of their recovery.

In other words, it is recommended to take into account the factors that affect the market value of debt. These include, in particular:

- the conditions for termination; terms of settlements provided by agreements;

- availability of collateral formed in accordance with the requirements of current legislation;

- claims on the quality and quantity of shipped products;

- financial position of counterparties.

Given this, different valuation options are possible: historical, current, sales, or true value.

IFRS recommends that the discounting procedure be applied to a variety of assets and liabilities. That is, both receivables and payables can be discounted. In accordance with IAS 19, the discounted value of accounts payable on a liability is calculated on a retirement benefit basis.

The value of the liability thus determined, together with the reasonable (established) payments, is presented as the discounted value of the expected future payments that arise from the provision of services by employees in the current and previous periods.

The application in the practice of commercial enterprises of the discounted value of receivables for accounting purposes will have a positive impact on the quality of reporting information for management purposes. This approach in accounting will allow the formation of reporting of Ukrainian enterprises in accordance with the requirements of IFRS without additional costs for its transformation.

Nevertheless, it should be emphasized that in Ukrainian conditions, the valuation of assets and liabilities at future value is not reliable enough due to the uncertainty and instability of the economic situation. In particular, there are often situations where, after receiving products or services, counterparties fail to meet or are unable to meet their debt repayment obligations. 
It is likely that part of such debt will remain outstanding even at the end of the statute of limitations. Therefore, it is important to conduct research related to the analysis of the basic principles of accounting for such debt, including their positioning at the theoretical level in terms of definitions. A comparison of the definitions of doubtful and bad debts in Ukraine and in International Accounting Standards (IAS) indicates a common basis, but there are different formulations and recommendations (Table 4).

Table 4

\section{Positioning and definition of doubtful and bad debts in Ukraine and in accordance with the recommendations of IAS}

\begin{tabular}{|c|c|c|}
\hline \multirow{2}{*}{$\begin{array}{l}\text { Normative } \\
\text { document }\end{array}$} & \multicolumn{2}{|r|}{ Definitions } \\
\hline & Doubtful debt & Bad debts \\
\hline $\begin{array}{l}\text { Ukrainian } \\
\text { normative } \\
\text { documents: } \\
\text { National } \\
\text { accounting } \\
\text { standards }\end{array}$ & \begin{tabular}{|l|} 
Current \\
receivables \\
for products, \\
goods, services \\
for which there \\
is uncertainty \\
about its \\
repayment by \\
the debtor
\end{tabular} & $\begin{array}{l}\text { Current receivables for which there is certainty that the debtor will } \\
\text { not repay or for which the statute of limitations has expired }\end{array}$ \\
\hline Tax Code & & $\begin{array}{l}\text { Bad debts: debts that meet one of the following characteristics: a) } \\
\text { debts on liabilities for which the statute of limitations has expired; b) } \\
\text { overdue debt, which is not repaid due to insufficiency of the property } \\
\text { of an individual, provided that the actions of the creditor aimed at the } \\
\text { forced recovery of the debtor's property did not lead to full repayment } \\
\text { of the debt; c) debts that have not been repaid due to insufficiency } \\
\text { of the property of business entities declared bankrupt in accordance } \\
\text { with the procedure established by law or deregistered as business } \\
\text { entities in connection with their liquidation; d) debt that is not repaid } \\
\text { due to insufficient funds received from the sale at public auctions } \\
\text { (public bidding) and otherwise provided by the terms of the pledge } \\
\text { agreement, the property of the borrower pledged as collateral for } \\
\text { the said debt, provided that other legal actions of the creditor forced } \\
\text { recovery of other property of the borrower did not lead to repayment of } \\
\text { the debt in full; e) debt, the recovery of which has become impossible } \\
\text { due to force majeure, natural disaster (force majeure), confirmed in } \\
\text { the manner prescribed by law; e) overdue debts of deceased natural } \\
\text { persons, as well as persons who have been declared missing, } \\
\text { incapable or declared dead by a court, as well as overdue debts of } \\
\text { natural persons sentenced to imprisonment. }\end{array}$ \\
\hline IAS & \multicolumn{2}{|c|}{$\begin{array}{l}\text { There is no definition. It is only indicated that if there is a probability of settlement of the } \\
\text { receivable, recognition of such receivable as an asset will be justified in the absence } \\
\text { of evidence to the contrary. }\end{array}$} \\
\hline
\end{tabular}

Notes: * - formed on the basis of $[7 ; 12 ; 13 ; 14]$ 
As you can see from the definition in Table 4, the internal approach focuses only on accounts receivable. In addition, these definitions can be specified and formulated more clearly. For example, you can specify the timing of debt repayment and guarantees of its provision.

Such clarifications would simplify the procedures for creating special and general reserves. Indeed, for this, the company must have reliable information about: the probability of debt repayment; return of debts in the past; the probability of debt repayment by a specific client [15, p.17].

The lack of a clear position on the criteria for recognizing receivables is hopeless, negatively affecting the reliability of accounting data. Therefore, as a criterion, it is advisable to use the recommendation of Article 257 of the Civil Code of Ukraine, according to which the general limitation period in Ukraine is three years [8, p.6]. In fact, it is at the end of such a period that the debt should be considered doubtful.

To recognize doubtful debts, we propose to use the following criteria:

1) non-repayment within the period established by the contract;

2) lack of provision of appropriate guarantees;

3 ) in case of initiation of bankruptcy proceedings against the payer;

4) reorganization of the entity.

The existence of doubtful debts requires an adequate economic response in the form of the creation of appropriate reserves. The formation of reserves will indirectly help prevent overstatement of income from sales.

In order for doubtful debts not to overestimate the real financial result, it is necessary to adjust the receivables to the amount of the provision for doubtful debts (with reference to the relevant costs).

The study of domestic and foreign practice shows the existence of different methods of calculating the amount of the provision for doubtful debts in accounting. In Ukraine, in accordance with paragraph $8 \mathrm{P}(\mathrm{S}) \mathrm{BU} 10$, the amount of the provision for doubtful debts can be determined by 2 methods: in the form of an absolute amount and a coefficient.

According to IFRS [16], to calculate the provision, it is necessary to establish the probability of debt collection for each debtor. Accruals are made only for debtors whose debt collection is questionable, and there are also two methods:

- accrual of the reserve as a percentage of revenue;

- distribution of receivables into several groups depending on the periods of delay and accrual of the reserve in the percentage, which is determined for each group.

In domestic practice, there are peculiarities of calculating and accounting for the reserve of doubtful debts for settlements on commodity transactions. Basically there are three main approaches: based on solvency; by share in net profit from sales; based on the classification of receivables.

When reflecting in the Order on Accounting Policy the provisions on the chosen method for calculating the allowance for doubtful debts and accounting for doubtful debts, a reasonable choice of one of the methods should be made (for each individual debtor; for each group of doubtful debtors; general for debtors, without dividing into groups).

In our opinion, it is necessary to accrue a provision for doubtful debts based on the results of the inventory of settlements only for some debtors who are in doubt about the 
repayment of debt, and it is known that the probability of debt is low (litigation, information about the difficult financial situation).

For other debtors, the provision should be accrued depending on the due date. The problem in this case is that in Ukraine there is not always information available on the basis of which it is possible to establish the solvency of customers with high reliability. Therefore, the probability of estimating the repayment of receivables has a material error, as a result of which decisions on the provision for doubtful debts are not always enforced.

An inventory of settlements is carried out to identify overdue debts. The results of the inventory are drawn up in the «Acts of inventory of settlements with buyers, suppliers and other debtors and creditors», approved by the Resolution «On approval of forms of primary accounting documentation for enterprises and organizations» from 28.12.1989 № 241.

However, this form has a number of shortcomings, including it does not contain information on the security of the debt (including whether there is at the time of inventory the debtor), the timing of doubtful debts, the statute of limitations. Complementing the above form with columns to display them will help increase the informativeness of the document.

Conclusions. Thus, the generalization of Ukrainian practice and foreign experience allows to form proposals aimed at improving accounting and applying an effective policy of repayment of liabilities. The application of the proposed provisions in practice will help improve the information base of decision-making and increase the efficiency of the trading company. The formed conceptual approach to the formation of an effective policy of repayment of receivables of trade enterprises allows to achieve optimization of the use of monetary resources, increase the efficiency of the enterprise and its profitability. In addition, the study shows that the effective development of a commercial enterprise is possible due to a combination of such important components of its activities as a good management information base and an effective policy of repayment of receivables. In this context, the justification of the stages of formation of the policy of repayment of receivables and the development of proposals for its evaluation, the formation of reserves for doubtful debts can be effectively used in the practice of various commercial enterprises.

Prospects for further research. A promising area of further research is the development of methods of analysis of receivables by actual indicators, the study of opportunities to improve communication and the formation of information support for trade and technological processes based on the use of modern information systems. In the future, an important continuation of research may be the study of the possibilities of computerization of management processes and analysis of receivables.

\section{References}

1. Vyshnevska, O. (2020). Social and Economic Development of Ukraine JanuaryJune 2020. State Statistics Service of Ukraine. Kyiv, 25 p. [in Ukrainian].

2. Akimova, N.S., \& Toporkova, O. V. (2017). Informatsiine zabezpechennia vnutrishnoho kontroliu debitorskoi ta kredytorskoi zaborhovanosti [The information support of the internal control of receivables and accounts payable]. Biznes Inform - Business Inform, 11, 312-317. Retrieved from: https://www.business-inform.net/ export_pdf/business-inform-2017-11_0-pages-312_317.pdf [in Ukrainian]. 
3. Makohin, Z.Ya., \& Atamanchuk, Z.A. (2020). Otsinka torhovelnoi efektyvnosti Ukrainy $z$ krainamy YeS [Evaluating the efficiency of Ukraine's trade with the EU countries]. Biznes Inform - Business Inform, 3, 16-25. Retrieved from: https://doi. org/10.32983/2222-4459-2020-3-16-25 [in Ukrainian].

4. Zhytnyi, P.Ye. (2007). Oblikova polityka v umovakh rozvytku finansovo-promyslovykh system: metodolohiia ta orhanizatsiia [Accounting policy in conditions of the development of financial and industrial systems: methodology and organization], monograph, Luhansk: SNU im. V. Dalia 352 p. [in Ukrainian].

5. Onyshchenko, V. (2020). Debitorska zaborhovanist [Receivables]. Holovbukh Chief Accountant, 29 may. Retrieved from: https://www.golovbukh.ua/article/7708debtorska-zaborgovans [in Ukrainian].

6. Svirydenko, A. (2020). Beznadiina zaborhovanist: vashe zapytannia - nasha vidpovid [Bad debts: Your question - our answer]. Podatky ta bukhhalterskyi oblik Taxes and accounting, 14. Retrieved from: https://i.factor.ua/ukr/journals/nibu/2020/ february/issue-14/article-107028.html [in Ukrainian].

7. Fadeyev, Yu.L. (2008). Spisaniye debitorskoy i kreditorskoy zadolzhennosti: prakticheskoye rukovodstvo [Writing off receivables and payables: a practical guide]. 2nd edition, corrections and additions, Moscow: Eksmo. 192 p. [in Russian].

8. Yancheva, L.M., Akimova, N.S., \& Novytska, N.V. (2007). Udoskonalennia metodyky obliku ta formuvannia rezervu sumnivnykh borhiv [Improvement of the accounting methodology and formation of the reserve of doubtful debts]. Ekonomichna stratehiia i perspektyvy rozvytku sfery torhivli ta posluh - Economic strategy and prospects for the development of trade and services, 1(5), 1, 3-8 [in Ukrainian].

9. Kolos, I. (2002). Formuvannia ratsionalnoi oblikovoi polityky pidpryiemstva [Formation of a rational accounting policy of the enterprise]. Visnyk podatkovoi sluzhby Ukrainy - Bulletin of the Tax Service of Ukraine, 47, 47-54 [in Ukrainian].

10. Rayzberg, B.A., Lozovskiy, L.Sh., \& Starodubtseva, Ye.B. (2007). Sovremennyy ekonomicheskiy slovar [Modern Dictionary of Economics], 5nd edition, corrections, Moscow: INFRA-M. 495 p. [in Russia].

11. Gryaznova, A.G., Fedotova, M.A., Eskindarov, M.A. et al. (2003). Otsenka stoimosti predpriyatiya (biznesa) [Assessment of the value of enterprise (business)], Moscow: INTERREKLAMA. 544 p. [in Russian].

12. Dembinskiy, N.V. (1957). Teoriya sovetskogo bukhgalterskogo ucheta [The theory of Soviet accounting], Minsk: Gos. izd-vo BSSR. 83 p. [in Russian].

13. The Verkhovna Rada of Ukraine (2010). The Law of Ukraine "Tax Code of Ukraine: as of 15.08.2012", dated 02.12.2010 № 2755-VI. Retrieved from: http://zakon2. rada.gov.ua/laws/show/2755-17 [in Ukrainian].

14. Ministry of Finance of Ukraine (1999). Order of the Ministry of Finance of Ukraine "Regulation (standard) of accounting 10 "Accounts receivable"' dated 08.10.99 № 237. Retrieved from: http://zakon.rada.gov.ua/cgi-bin/laws/main. cgi?nreg=z0725-99 [in Ukrainian].

15. Yendovitskiy, D.A., \& Kupryushina, O.M. (2001). Podkhody k raskrytiyu informatsii o debitorskoy i kreditorskoy zadolzhennosti v bukhgalterskoy otchetnosti [Approaches 
to the disclosure of information on accounts receivable and accounts payable in the financial statements], Auditor - Auditor, 12, 15-19 [in Russian].

16. List of IFRS Standards. IFRS. Retrieved from: https://www.ifrs.org/issued-standards/ list-of-standards/ [in English].

Статтю отримано 8 вересня 2020 р.

Article received September 8, 2020 